\title{
Are oysters being bored to death? Influence of Cliona celata on Crassostrea virginica condition, growth and survival
}

\author{
John M. Carroll ${ }^{1,3, *}$, Kathryn A. O'Shaughnessy ${ }^{1,2}$, Grant A. Diedrich ${ }^{1}$, \\ Christopher M. Finelli ${ }^{1}$
}

${ }^{1}$ Department of Biology and Marine Biology, University of North Carolina Wilmington, Wilmington, NC 28403, USA

${ }^{2}$ Present address: Louisiana Universities Marine Consortium, Chauvin, LA 70344, USA

${ }^{3}$ Present address: Department of Biology, Georgia Southern University, Statesboro, GA 30460, USA

\begin{abstract}
The boring sponge Cliona celata is a nuisance species that can have deleterious effects on eastern oyster Crassostrea virginica growth, condition, and survival. Surprisingly, however, these effects have not been well documented and when examined, results have been equivocal. In this study, we provide a direct comparison of growth, condition, and survival of spongecolonized and uncolonized oysters in southeast North Carolina in 2 separate experiments. In the first experiment, sponge-colonized oysters exhibited significantly slower growth rates, reduced condition, and lower survival relative to uncolonized oysters, although results may have been confounded by oyster source. In the second experiment, using smaller oysters from the same source population, growth rate was again significantly reduced in colonized oysters relative to uncolonized oysters, however neither condition nor survival differed. In field surveys of the same population, colonized individuals across a range of sizes demonstrated significantly reduced condition. Further, condition index was negatively correlated with sponge biomass, which was positively correlated with oyster size, suggesting that the impact of the sponge changes with ontogeny. By investigating clearance rates, tissue isotopic and nutrient content, as well as caloric value, this study provides further evidence that sponge presence causes the oysters to divert energy into costly shell maintenance and repair at the expense of shell and somatic growth. Thus, although variable, our results demonstrate negative impacts of sponge infestation on oyster demographics, particularly as oysters grow larger.
\end{abstract}

KEY WORDS: Eastern oyster $\cdot$ Crassostrea virginica $\cdot$ Boring sponge $\cdot$ Cliona celata $\cdot$ Survival Growth

\section{INTRODUCTION}

Clionid sponges commonly live in a network of cavities and tunnels that they excavate in calcium carbonate substrates (Hoeksema 1983), and they infest commercial shellfish operations globally (Alagarswami \& Chellam 1978, Rosell et al. 1999, Fromont et al. 2005, Carver et al. 2010). Cliona spp. are the largest and most destructive boring sponges in the Atlantic (Rutzler 2002). They penetrate carbonate

\footnotetext{
${ }^{*}$ Corresponding author: jcarroll@georgiasouthern.edu
}

rock and shells using primarily chemical and mechanical methods (Rutzler \& Rieger 1973, Pomponi 1980), which reduces shell integrity. Colonized molluscs produce extra shell material to compensate for the inward progression of the sponge (Stefaniak et al. 2005, Le Cam \& Viard 2011). Producing this extra shell material is costly (Palmer 1992) and can impact somatic growth, condition, and reproduction of shellfish bored by a variety of pests (Handley 1998, Fromont et al. 2005).

() The authors 2015. Open Access under Creative Commons by Attribution Licence. Use, distribution and reproduction are unrestricted. Authors and original publication must be credited. 
Numerous studies have examined clionid infestation rates and burrowing activities in oyster shells (Warburton 1958c, Alagarswami \& Chellam 1978, Thomas 1979, Wesche et al. 1997, Carver et al. 2010, Daume et al. 2010), although surprisingly few have considered the impacts on oyster condition and growth rates (but see Schleyer 1991, Rosell et al. 1999). In temperate regions of the USA Cliona celata is the dominant excavating sponge on oyster reefs (Hartman 1958). C. celata causes substantial damage to the shells of eastern oysters Crassostrea virginica, and can cause considerable economic loss of wild and cultured harvest (Warburton 1958a). While the sponge could cause mortality in larger, older oysters (Warburton 1958b, Thomas 1979, Rosell et al. 1999), much of the economic loss is due to the reduced market value for the oysters because of their brittle shells (Carver et al. 2010).

Somewhat surprisingly, the impacts of the boring sponge on $C$. virginica growth and condition have not been well documented. Warburton (1958b) suggested that the meat quality of infested oysters might be lower than those free of infestation, although only a few oysters showed diminished growth as a result of heavy sponge infestation, and the author provided no analysis. Kennedy \& Breisch (1981) suggested that the presence of the boring sponge might stunt oyster growth, but offered no data in their review of oyster research for the state of Maryland. Oyster larval settlement appears to be hindered, and larval mortality rates higher in the presence of the boring sponge (Barnes et al. 2010), although more recent studies have suggested only a limited impact on oyster larval settlement (Dunn et al. 2014b). Other boring organisms, particularly spionid polychaetes from the genus Polydora, have been shown to impact condition and survival of oysters (Wargo \& Ford 1993, Handley \& Bergquist 1997, Chambon et al. 2007). This reduction in condition is attributed to increased secretion of nacre, resulting in poor oyster condition due to the reallocation of energy to shell formation, loss of internal shell volume, and/or a reduction in feeding as the result of an irregular shaped cavity (Handley 1998). Since oysters also respond to the boring sponge by diverting energy into the secretion of new shell layers to protect the inner cavity (Thomas 1979, Hoeksema 1983), it may be expected that boring sponges have similar effects on the condition and growth of Crassostrea spp.

Despite the expectation of negative effects caused by the presence of the boring sponge, colonized molluscs have shown variable results in regards to condition and growth. The pearl oyster Pinctada maxima experience stunted growth when colonized by a boring sponge (Fromont et al. 2005), whereas the European flat oyster Ostrea edulis showed no correlation between sponge infestation and size or condition (Rosell et al. 1999). Other studies have shown that the boring sponge might even have a positive impact on Cape rock oyster Striostrea margaritacea condition and reproduction (Schleyer 1991). The abalone Haliotis iris showed reduced growth and condition in individuals with shell lesions caused by unspecified boring organisms in one study (Nollens et al. 2003), but growth was unaffected by boring organisms in a different study (Dunphy \& Wells 2001), and infestation did not appear to have negative effects on Haliotis tuberculata (Clavier 1992). In one of the most thorough clionid-mollusc studies, Stefaniak et al. (2005) showed that bored periwinkle snails had thicker aperture lips, less shell mass, lower tissue dry weight, weaker shells, and were more susceptible to predation than unbored snails. Investigations of the gastropod Crepidula fornicata colonized with $C$. celata, however, did not show similar negative impacts on growth, condition, or reproduction output (Le Cam \& Viard 2011).

Although $C$. virginica responds negatively to boring organisms, the effects of boring $C$. celata on eastern oyster growth or survival is still relatively unresolved. The sponge attacks the hinge of the oyster (affecting its ability to open and close), the site of adductor muscle attachment, and in heavy infections can penetrate the inner cavity (Fig. 1), resulting in inner surface irregularities and causing the oysters to secrete nacreous layers to protect the cavity from penetration (Warburton 1958b, Thomas 1979, Hoeksema 1983), which is metabolically costly (Palmer 1992). While boring sponges can have a major economic impact on cultured oysters (Warburton 1958a, Wesche et al. 1997, Carver et al. 2010), the boring sponge has also recently begun to be problematic for oyster restoration efforts (Dunn et al. 2014b). In fact, it has been suggested that the boring sponge may contribute to the limited distribution of oyster reefs in intertidal regions in the southeast USA (Lunz 1943, Fodrie et al. 2014). Further, boring sponge infestations have been implicated in the mortality of older, severely colonized oysters (Warburton 1958b, Carver et al. 2010), likely through a combination of other stressors such as disease, parasites, and harsh conditions (Guida 1977). Thus, the expectation is that boring sponges will have a negative impact on eastern oyster demographic rates.

Due to the high economic and ecological value of C. virginica, it is important to more fully under- 

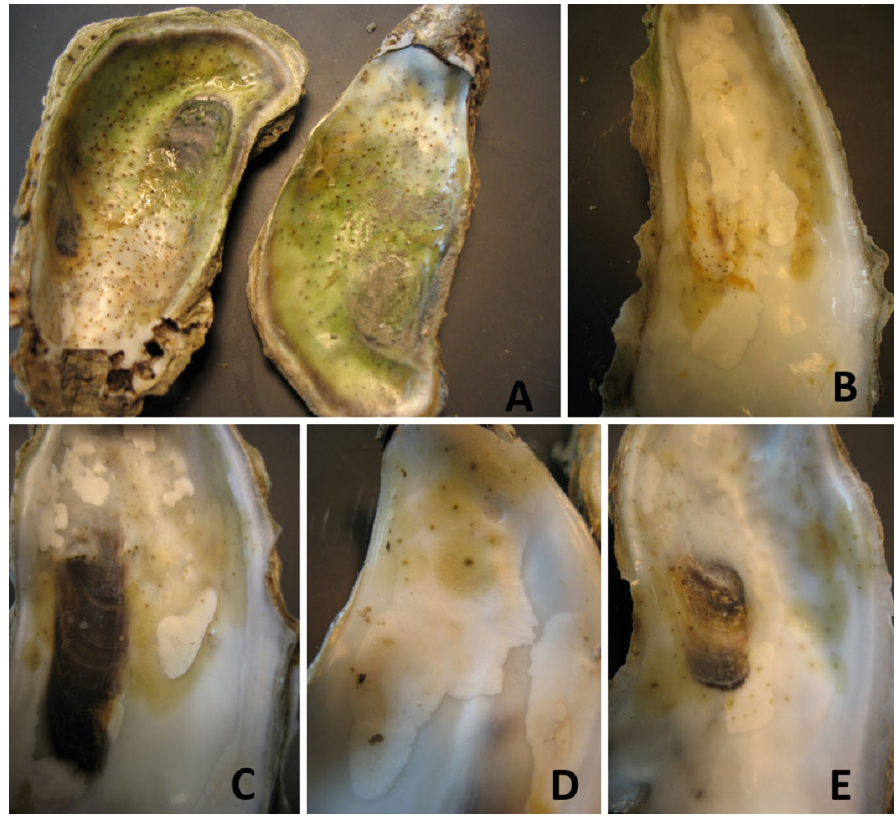

Fig. 1. Internal shell cavities of eastern oysters Crassostrea virginica colonized by boring sponge Cliona celata, showing (A) a heavily infested oyster with uneven surface irregularities on both valves, and (B-E) close-ups of various stages of penetration and shell repair in oysters collected from Hewlett's Creek, Wilmington, North Carolina

stand these negative impacts, therefore, the objective of this study was to make a direct comparison of growth, condition, and survival between colonized and uncolonized oysters in southeast North Carolina. We hypothesized that growth and condition would be reduced for colonized oysters, and that colonized oysters exposed to predators would experience disproportionately higher mortality rates.

\section{MATERIALS AND METHODS}

\section{Experiment 1}

Study sites

This study was conducted at 2 intertidal sites in New Hanover County, North Carolina, near the city of Wilmington: the University of North Carolina Wilmington (UNCW) research lease in Hewletts Creek (CL; $\left.34^{\circ} 10^{\prime} 35^{\prime} \mathrm{N}, 77^{\circ} 50^{\prime} 33^{\prime} \mathrm{W}\right)$ and the Center for Marine Sciences $\left(\mathrm{CMS}^{\prime} 34^{\circ} 08^{\prime} 26^{\prime} \mathrm{N}, 7^{\circ} 51^{\prime}\right.$ $\left.47^{\prime} \mathrm{W}\right)$, located on the Atlantic Intracoastal Waterway. Tides in this area are mesotidal and semidiurnal with strong diurnal inequality (Nelson et al. 2004).

\section{Oyster growth and survival}

Eastern oysters Crassostrea virginica Gmelin 1791 colonized by Cliona celata (Grant 1826) were collected from Carolina Mariculture Company, a commercial oyster farm in Cedar Island, NC. The commercial oysters were diploid oysters spawned from local broodstock, continuously submerged in floating cages and protected from predation. Uncolonized oysters were collected from the intertidal zone at CL. Both locations have similar water quality characteristics (see Figs. S1-S3 in the Supplement at www.int-res.com/articles/suppl/d117p031_ supp.pdf). Oysters were visually inspected to determine infestation. Each oyster was uniquely tagged by adhering a numbered stainless steel washer to its shell with Z-spar SplashZone Compound (Britton-Simmons 2004). It was then digitally photographed, and initial shell area of the left valve (LVA) was measured using ImageJ (National Institute of Health) image analysis software (Newell et al. 2007, Kelly et al. 2011). Oysters were held in flowing, ambient seawater with constant aeration at the UNCW CMS from the time of collection to the time of deployment.

At each site, 4 caged and 4 uncaged plots were created. Each plot received a $5 \mathrm{~cm}$ thick shell layer as a foundation, and 3 colonized and 3 uncolonized oysters were placed in each plot. Caged plots were constructed by building circular cages $17 \mathrm{~cm}$ tall and $35 \mathrm{~cm}$ in diameter using $12 \mathrm{~mm}$ diamond mesh around the plots. Cages were constructed to prevent predation mortality on the enclosed oysters. Paired caged and uncaged plots were placed parallel to the tide line, and positions were marked by a PVC stake. Plots were deployed at CMS on 23 June 2010 and at CL on 25 June 2010. All plots were recovered on 13 September 2010, bagged according to site and treatment, and frozen at $-20^{\circ} \mathrm{C}$.

All recovered oysters were cleaned of epibionts and digitally photographed. Absolute growth was calculated by measuring the final surface area using ImageJ software. However, absolute measurements could be confounded by starting size (Kaufmann 1981, Kelly et al. 2011). To standardize growth rate to oyster size, the daily specific growth rate (SPG) was calculated using the following formula:

$$
\mathrm{SPG}=\frac{\left(\ln A_{2}-\ln A_{1}\right)}{t_{2}-t_{1}}
$$


where $A$ is the area of the oyster shell at the beginning and the end of the experiment, and $t_{2}-t_{1}$ is the time in days for the deployment (Kelly et al. 2011). Mortality was estimated as the number of missing and dead oysters at the end of the experiment. Predation was assumed to be the cause of missing oysters, while the source of mortality for those recovered dead with no visible damage could not be determined.

Oysters were then weighed and dissected. Tissues were placed into pre-weighed aluminum tins and dried to a constant mass at $70^{\circ} \mathrm{C}$ for $48 \mathrm{~h}$. Oyster condition index (CI) was calculated using the following equation:

$$
\mathrm{CI}=\frac{\mathrm{TDW}}{\mathrm{WW}-\mathrm{SW}} \times 100
$$

where TDW is the dry weight of the tissues, WW is the whole wet weight, and SW is the shell weight (Rheault \& Rice 1996). Finally, to determine mass of sponge tissue, all oyster shells were combusted at $450^{\circ} \mathrm{C}$ for $4 \mathrm{~h}$ to burn off all organic matter. Shells without boring sponges lost a mean of $1.72 \pm 0.13 \%$ mass during combustion. Shell weights for oysters with sponges were corrected for this loss, and the difference between the corrected shell weight and the combusted shell weight was determined to be the biomass of the sponge.

\section{Experiment 2}

Although using SPG should allow for comparisons among different oyster populations, ages, and sizes (Kelly et al. 2011), the differential population sources and initial sizes of oysters in Expt 1 may have confounded our results. Therefore, we repeated this experiment, using only sponge-colonized and uncolonized oysters collected from intertidal reefs at CL. Oysters were visually inspected for signs of sponge infestation, and assigned as either 'sponge' or 'no sponge.' Oysters were assigned a unique ID number, using wire tags superglued onto the flattened portion of the right valve, then digitally photographed, and as above, initial shell area was measured using Image J image analysis software. Oysters were held in flowing, ambient seawater with constant aeration at the UNCW CMS from the time of collection until the time of deployment.

Cages were constructed by fixing a $15 \times 15 \times 15$ $\mathrm{cm}$ cage with $15 \mathrm{~mm}$ wire mesh on one end of a $35 \times$ $20 \times 3 \mathrm{~cm}$ cement slab, leaving the other end open (see Fig. S4 in the Supplement). For each cage, either 5 uncolonized or 5 colonized oysters were placed inside the cage; additionally, 5 individuals of the same treatment were placed outside the cage, for a total of 5 cages for each treatment. Cages were deployed in a paired, blocked design (1 cage of each treatment), separated by $5 \mathrm{~m}$, and run parallel to the shore at CMS for a period of $12 \mathrm{wk}$, from 29 August to 14 November 2014. Cages were checked biweekly for partial burial and fouling, and cleaned if necessary. At the end of the experiment, all oysters and shells were collected and frozen at $-20^{\circ} \mathrm{C}$ until analysis.

As above, all recovered oysters were cleaned of epibionts before being digitally photographed and measured for final shell area. Absolute growth was calculated and standardized using SPG. Epifauna were identified and enumerated to examine differences between treatments. No oysters outside the cages were recovered, although many crushed shell pieces were present, suggesting all the uncaged oysters were likely consumed. Mortality was only calculated for oysters in the cages. Finally, oysters were weighed and dissected to determine condition as described above. Sponge biomass was also calculated as above.

After TDW was determined for these oysters, the dry tissues were ground up and homogenized using a mortar and pestle. Since the presence of sponges can impact the oysters' hinge and valve operation and alter cavity space due to nacreous layer secretions (Thomas 1979, Hoeksema 1983), which has been suggested to alter feeding abilities in oysters infested with spionid polychaetes (Handley 1998), the potential impact of the sponge presence on filtration and/or assimilation efficiency of oysters in the field was examined using stable isotopes. Different isotopic composition between colonized and uncolonized oysters could reflect differential assimilation of food particles, tissue condition, or tissue growth (Dattagupta et al. 2004, Malet et al. 2007, Le Vay \& Gamboa-Delgado 2011). Compound specific carbon $(\mathrm{C})$ and nitrogen $(\mathrm{N})$ isotopic analyses were made using a Costech 4010 elemental analyzer interfaced with a Thermo Delta V Plus mass spectrometer in the Stable Isotope Biochemistry Lab at the UNCW CMS. This technique also provides a C:N ratio, which can be used as a proxy for condition and protein synthesis (Gnaiger \& Bitterlich 1984, Rainer \& Mann 1992).

Finally, the remaining dried, homogenized tissues from each oyster were analyzed for energy content using an IKA 2000 basic calorimeter. Between 0.2 and $1 \mathrm{~g}$ of dried tissue was placed into pre-weighed combustible sample cups with a known energy density of $18.745 \mathrm{~kJ} \mathrm{~g}^{-1}$. Caloric density estimates 
for bombs were calibrated using $1 \mathrm{~g}$ benzoic acid $\left(\mathrm{C}_{6} \mathrm{H}_{5} \mathrm{COOH}\right)$ pellets with a known energy density of $26.460 \mathrm{~kJ} \mathrm{~g}^{-1}$. This method calculates energy content per unit dry mass of oyster tissues, which can be considered a proxy for lipid content and organism condition (Anthony et al. 2000, McKinstry et al. 2013).

\section{Clearance rate}

To test if sponge presence affected oyster feeding, we conducted clearance rate (CR) experiments. Twelve 2-liter beakers were filled with $1500 \mathrm{ml}$ of $1 \mu \mathrm{m}$ filtered, UV-sterilized seawater and $500 \mathrm{ml}$ concentrated mixed algae containing a mixture of Isochrysis galbana affinis Tahiti (T-iso), Chaetoceros muelleri, Tetraselmis sp., and Thalassiosira pseudonana, at a concentration of $\sim 2.2$ million cells $\mathrm{ml}^{-1}$, obtained from the UNCW Shellfish Research Hatchery. Jars were bubbled to help mix the algae. Initial samples were taken using $60 \mathrm{ml}$ syringes and filtered onto $25 \mathrm{~mm}$ glass fiber filters (GFF). After taking initial samples, 6 jars received a single uncolonized oyster, and the other 6 received a single colonized oyster. Oysters were allowed to filter for $4 \mathrm{~h}$ after opening. Those oysters that did not open within $1 \mathrm{~h}$ were discounted. After $4 \mathrm{~h}$, a final sample was taken with a 60 $\mathrm{ml}$ syringe and filtered as described above. Jars were then refilled, and each oyster was prevented from opening by using rubber bands. Initial samples were taken as described, rubber-banded oysters were placed back into the jars, and after $4 \mathrm{~h}$ a final sample was taken. This served as a control for each oyster. After control trials, all oysters were photographed, weighed, and dissected as described previously. The experiment was repeated 5 times; however, due to a number of oysters not feeding, only 40 oysters were used for subsequent CR analysis ( $\mathrm{n}=21$ for uncolonized and 19 for colonized oysters).

Filters were frozen, extracted with $90 \%$ acetone and analyzed on a Turner fluorometer. CR $\left(1 \mathrm{~h}^{-1}\right)$ was estimated for each oyster using the method outlined by Coughlan (1969):

$$
\mathrm{CR}=\frac{V}{t} \ln \frac{C_{\mathrm{B} 0} C_{\mathrm{C} t}}{C_{\mathrm{B} t} C_{\mathrm{C} 0}}
$$

where $V$ is the volume of each jar (2 l), $C_{C t}$ is the concentration of algae in suspension $\left(\mu \mathrm{g}^{-1}\right)$ at time $t(t=$ $4 \mathrm{~h}$ ) during a control trial, and $C_{\mathrm{C} 0}$ is the initial concentration of algal particles during a control trial which accounts for the removal of particles by gravitational deposition (Coughlan 1969, Sumerel \& Finelli 2014), or in this case, potential clearance by the bor- ing sponge. Similarly, $C_{\mathrm{B} t}$ is the algal concentration at time $t$ during the experimental feeding trials and $C_{\mathrm{B} 0}$ is the initial algal concentration during a feeding trial accounting for removal of particles by deposition and feeding (Coughlan 1969, Sumerel \& Finelli 2014). Filtration was standardized per gram dry weight, and the allometric relationship between oyster size and CR was calculated for uncolonized and colonized oysters, following Dame (1996), to determine if the relationship was affected by sponge presence using:

$$
\mathrm{CR}=\mathrm{aTDW}^{b}
$$

where TDW is the tissue dry weight and $a$ and $b$ are model parameters.

\section{Field prevalence}

While reefs in southeast North Carolina are almost exclusively intertidal (Carroll et al. 2015), and therefore have typically been considered a refuge from the boring sponge due to periods of exposure (Hopkins 1962), the boring sponge does infest local intertidal reefs (C. M. Finelli pers. obs.). To calculate the prevalence of sponge infestation on intertidal reefs, thirty $0.04 \mathrm{~m}^{2}$ quadrats were haphazardly tossed onto intertidal reefs during tidal exposure in July 2013. All living oysters were excavated from the quadrats, returned to the lab, and frozen. Oysters from each quadrat sample were enumerated, the presence or absence of sponge noted, and then oysters were measured and dissected for TDW and CI. Additionally, all oyster spat and barnacles were also enumerated.

\section{Statistical analysis}

For Expt 1, we tested the hypothesis that sponge presence affected SPG using a 3-way ANOVA. The response was SPG, and the predictors were site (CMS or CL), cage treatment (caged or uncaged), and sponge presence (colonized or uncolonized) as the fixed factors. To test for significant differences among individual treatments, post hoc multiple comparisons were made using Tukey's HSD test, which maintains a family-wide $\alpha$ given multiple comparisons. Results were considered significant at $\mathrm{p} \leq 0.05$.

Likewise, to test whether sponge presence had an impact on oyster survival, arcsine square-root transformed mortality values were analyzed using the 3way ANOVA design described above. A differential predation rate between colonized and uncolonized 
oysters was assumed if there was a significant cage $x$ sponge treatment interaction, i.e. if the mortality of colonized oysters was dependent on cage presence or absence.

Since neither site nor caging impacted oyster growth, a series of $t$-tests were conducted with the presence/absence of the sponge as the factor for tissue dry weight (TDW), shell weight, size, and condition. To account for testing multiple hypotheses, we used the false discovery rate (FDR) technique to calculate $\alpha$ (Benjamini \& Hochberg 1995).

For Expt 2, all uncaged oysters were gone after $2 \mathrm{wk}$, and only 1 site was used. To improve statistical power, the hypothesis that sponge presence affected oyster growth and condition was tested using a 1-way blocked ANOVA with treatment (uncolonized or colonized) as the fixed factor and cage (1 to 5) as the blocking factor for SPG, CI, TDW, shell size, shell weight, C:N ratio and energy content. Survival was analyzed using a $t$-test. $\delta^{15} \mathrm{~N}$ and $\delta^{13} \mathrm{C}$ stable isotopic composition (\%) for colonized and uncolonized oysters were compared using a $t$-test. As above, the FDR was used to calculate $\alpha$.

Combining oysters from Expts 1 and 2, we also determined any relationship between $\mathrm{CI}$ and oyster size using a linear regression model, with condition as the dependent variable and shell area as the independent variable for either uncolonized $(n=46)$ or colonized $(\mathrm{n}=35)$ oysters. Similarly, we also combined data from Expts 1 and 2 to investigate the relationship between sponge biomass and both oyster condition and size. We attempted to fit linear, logarithmic, logistic and power functions to the data sets, and used Akaike's information criterion (AIC) to determine the model of best fit.

In order to investigate whether the presence of the sponge affected the ability of oysters to filter efficiently, a $t$-test was used to determine differences in square-root transformed clearance rates. Results were considered significant at $p \leq 0.05$. The parameter estimates for the allometric clearance rate relationships described above were determined using SigmaPlot v.11.0 statistical software, and differences between the exponent parameter $b$ were investigated with a $t$-test.

For field oysters, the difference in condition between sponge-colonized and uncolonized oysters was analyzed using a $t$-test. In addition, the allometric relationship between shell size and biomass were compared between uncolonized and colonized oysters as an index of oyster growth (Pollack et al. 2011). The relationship between shell length and shell weight can be expressed as a power function (Dame 1972):

$$
\mathrm{LVL}=a \mathrm{TDW}^{b}
$$

where LVL is the left valve length (mm), TDW is the tissue dry weight, and $a$ and $b$ are empirically derived coefficients. Parameter estimates were determined as above, and potential differences in the exponent $b$ were determined using a $t$-test. As above, we also investigated the relationship between sponge biomass and oyster CI or oyster size (shell length) using linear regressions.

\section{RESULTS}

\section{Experiment 1}

Sponge-colonized oysters were significantly larger than uncolonized oysters at the start of the experiment (3-way ANOVA, $F_{1,43}=19.704, \mathrm{p}<0.001$ ), so SPGs were used to correct for this difference. Colonized oysters grew at significantly slower rates compared to uncolonized oysters (3-way ANOVA, $F_{1,32}=8.509, \mathrm{p}=$ $0.007)$. However, neither cage treatment $\left(F_{1,32}=0.114\right.$, $\mathrm{p}=0.738)$ nor site $\left(F_{1,32}=0.298, \mathrm{p}=0.590\right)$ had significant effects on oyster SPGs (Fig. 2A).

Oyster survival was significantly higher inside than outside cages $\left(F_{1,24}=34.031, \mathrm{p}<0.001\right.$; Fig. $\left.2 b\right)$. In addition, colonization by boring sponges significantly reduced oyster survival $\left(F_{1,24}=8.117, \mathrm{p}=\right.$ $0.009)$. Survival did not differ by site $\left(F_{1,24}=0.460\right.$, $\mathrm{p}=0.504)$, and there was no significant cage $\times$ sponge interaction $\left(F_{1,24}=0.723, \mathrm{p}=0.404\right)$. The initial size of the oyster did not have a significant effect on survival (2-way ANOVA, $F_{1,90}=1.153, \mathrm{p}=0.286$ ).

TDW was marginally higher in colonized oysters $(t=-1.979, \mathrm{p}=0.057 ;$ Fig. 3A), and shell weight was also significantly higher in colonized oysters $(t=$ $-2.616, p=0.014$, Fig. 3B). However, mean $( \pm \mathrm{SE}) \mathrm{CI}$ was significantly higher for uncolonized oysters $(8.75$ $\pm 0.51)$ than those that were colonized $(3.62 \pm 0.39, t=$ $6.580, p<0.001$; Fig. 3C). Mean sponge biomass for the colonized oysters recovered alive was $0.36 \pm 0.06$ g dry weight.

\section{Experiment 2}

Using oysters from the same source population, SPG also significantly differed by treatment $\left(F_{1,38}=\right.$ 8.369, $\mathrm{p}=0.006$; Fig. 4), and there was no block effect of cage $\left(F_{1,38}=0.034, \mathrm{p}=0.855\right)$. Unlike Expt 1 , uncolonized oysters were significantly larger at the end of the experiment $(60.3 \pm 1.7 \mathrm{~mm} \mathrm{LVL})$ than colonized 

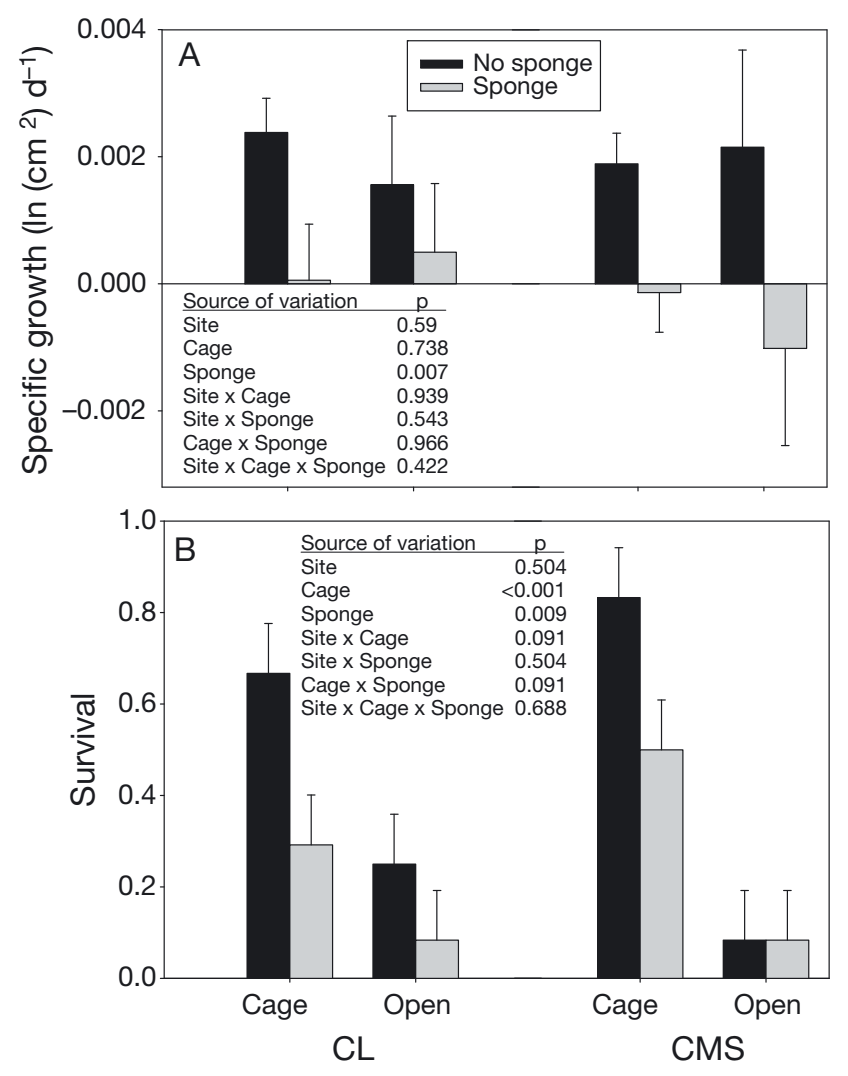

Fig. 2. Mean $( \pm \mathrm{SE})(\mathrm{A})$ specific growth rate and (B) survival of eastern oysters Crassostrea virginica colonized with boring sponges Cliona celata (gray bars), and uncolonized oysters (black bars), within or outside cages at 2 sites in Wilmington, New Hanover County, North Carolina during Expt 1. CL: University of North Carolina (UNCW) Clam Lease in Hewletts Creek; CMS: research dock at the Center for Marine Sciences at UNCW

oysters $\left(52.4 \pm 2.6 \mathrm{~mm}_{;} F_{1,38}=5.307, \mathrm{p}=0.027\right)$. Also unlike Expt 1, there was no difference in TDW (uncolonized $=0.61 \pm 0.07 \mathrm{~g}$; colonized $=0.57 \pm 0.06$ $g_{i} F_{1,38}=0.243, \mathrm{p}=0.625$ ), shell weight (uncolonized $=19.0 \pm 1.6 g_{i}$ colonized $=16.2 \pm 1.6 g_{i} F_{1,38}=1.341$, $\mathrm{p}=0.254$ ) or CI (uncolonized $=8.87 \pm 0.57$; colonized $\left.=8.01 \pm 0.50 ; F_{1,38}=1.281, \mathrm{p}=0.265\right)$. The mean sponge biomass for living oysters was $0.12 \pm 0.02 \mathrm{~g}$ dry weight.

$\delta^{15} \mathrm{~N}$ values did not differ between colonized $(8.80 \pm 0.37 \%)$ or uncolonized oyster tissues $(8.75 \pm$ $0.32 \% ; t=-0.494, \mathrm{p}=0.624)$. Similarly, $\delta^{13} \mathrm{C}$ values also did not differ between colonized $(-18.77 \pm$ $0.59 \%$ ) and uncolonized oysters $(-18.80 \pm 0.43 \%$; $t=$ $-0.171, \mathrm{p}=0.865)$. C:N ratios of ground oyster tissues with sponge attached $(4.76 \pm 0.13)$ also did not vary from those without sponge $\left(4.61 \pm 0.11 ; F_{1,38}=0.657\right.$, $\mathrm{p}=0.423)$. Energy content of the oyster tissues was also not significantly different between oysters with

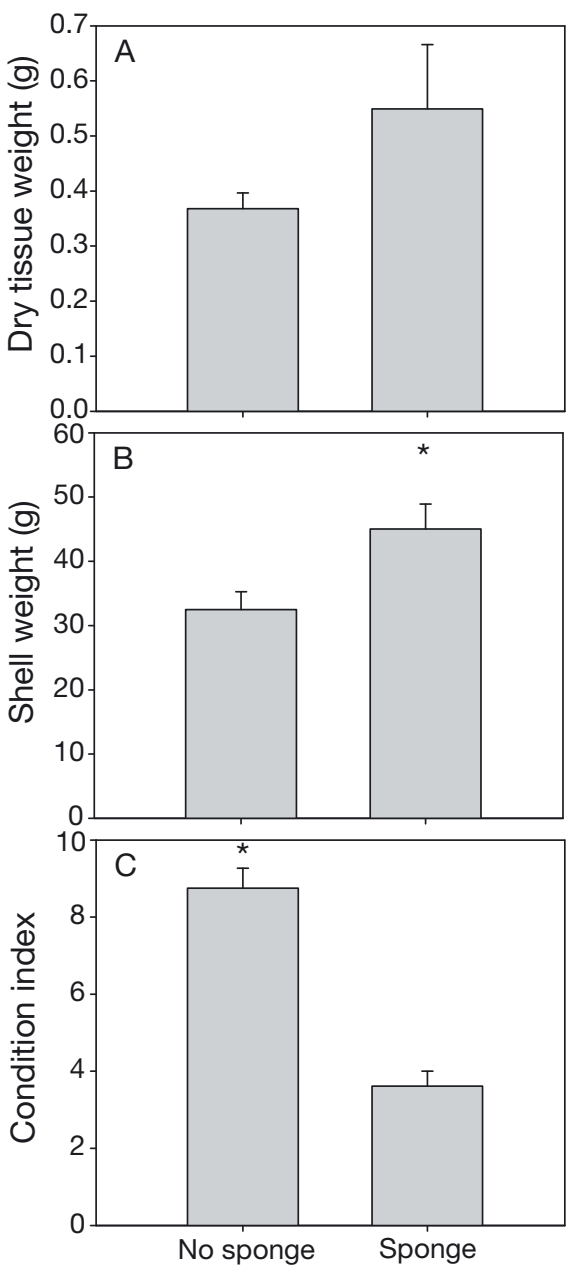

Fig. 3. Mean $( \pm \mathrm{SE})(\mathrm{A})$ dry tissue weight, (B) shell weight, and (C) condition index of eastern oysters Crassostrea virginica with $(\mathrm{n}=12)$ and without $(\mathrm{n}=22)$ boring sponge Cliona celata attachment across both sites and cage treatments during Expt 1. Stars denote significant differences

$\left(16.65 \pm 0.22 \mathrm{~kJ} \mathrm{~g}^{-1}\right)$ and without sponges $(16.46 \pm$ $0.25 \mathrm{~kJ} \mathrm{~g}^{-1} ; F_{1,38}=0.301, \mathrm{p}=0.587$ ).

Unfortunately, no oysters were recovered from outside any of the cages, regardless of sponge treatment. Many bits of broken shell were found, indicating that oysters had likely been consumed. Within the cages, survival of uncolonized oysters $(72 \pm 15 \%)$ was lower than that of colonized oysters $(92 \pm 5 \%)$; however, this difference was not significant $(t=$ $-1.270, p=0.240$ ).

A number of epifauna were found to recruit to the oysters in this study. These included oyster spat, barnacles, mussels Brachidontes sp., slipper shell snails Crepidula sp., and jingle shells Anomia simplex. There was no significant difference in recruitment of oyster spat to either colonized or uncolonized oysters 


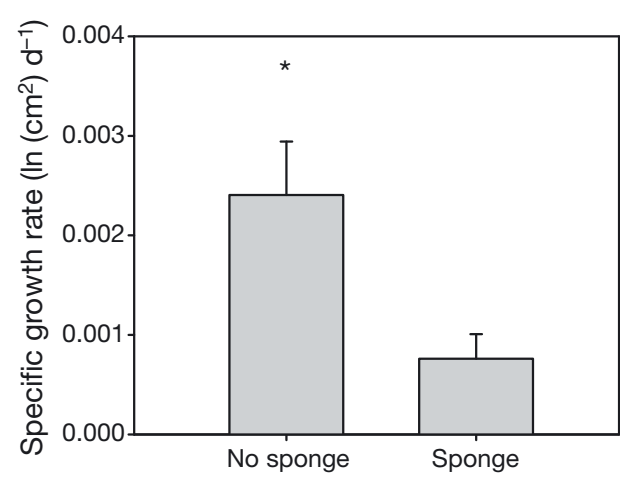

Fig. 4. Mean $( \pm \mathrm{SE})$ daily specific growth rate for eastern oysters Crassostrea virginica with $(\mathrm{n}=23)$ and without $(\mathrm{n}=18)$ boring sponge Cliona celata infestation during Expt 2 at the University of North Carolina Center for Marine Science. Star denotes significant difference

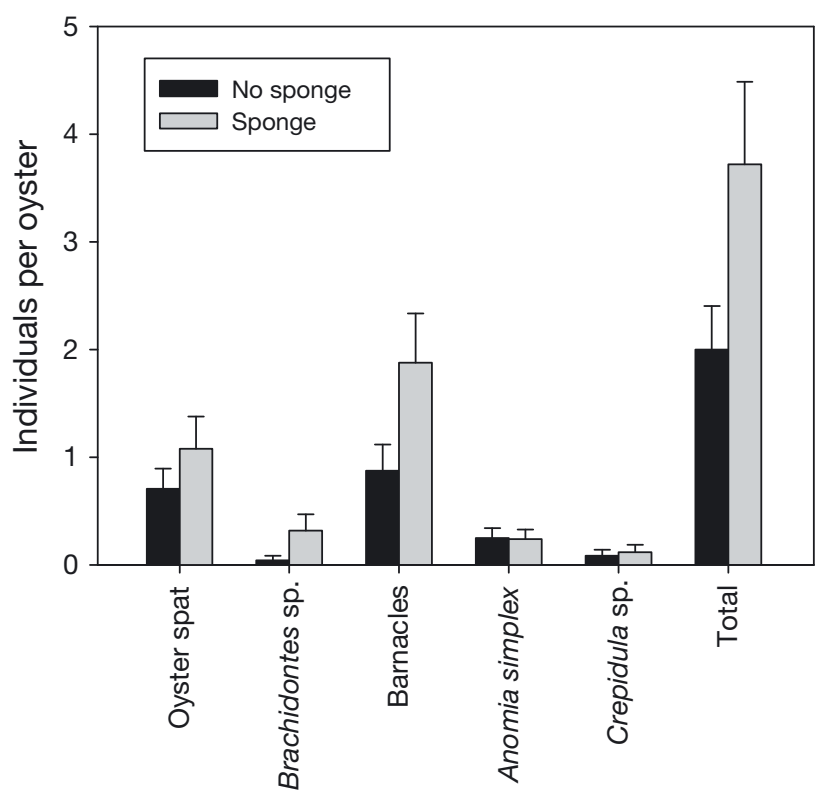

Fig. 5. Mean $( \pm \mathrm{SE})$ abundance of epifauna recruiting to individual eastern oyster Crassostrea virginica with or without boring sponge Cliona celata infestation during Expt 2 at the

University of North Carolina Center for Marine Science

$\left(F_{1,46}=1.075, \mathrm{p}=0.305\right)$. Mussels and barnacles were almost twice as abundant on colonized compared to uncolonized oysters, although these differences were not significant (mussels: $F_{1,46}=3.139, \mathrm{p}=0.083$; barnacles $F_{1,46}=3.719, \mathrm{p}=0.060$, Fig. 5). Similarly, neither slipper shells $\left(F_{1,46}=0.171, \mathrm{p}=0.681\right)$ nor jingle shells differed between colonized and uncolonized oysters $\left(F_{1,46}=0.006, p=0.937\right.$; Fig. 5$)$.

When oysters from both experiments were combined, there was no significant relationship between uncolonized oyster size and tissue condition $\left(\mathrm{r}^{2}=\right.$ $0.013, p=0.493$; Fig. 6 ). However, there was a signif-

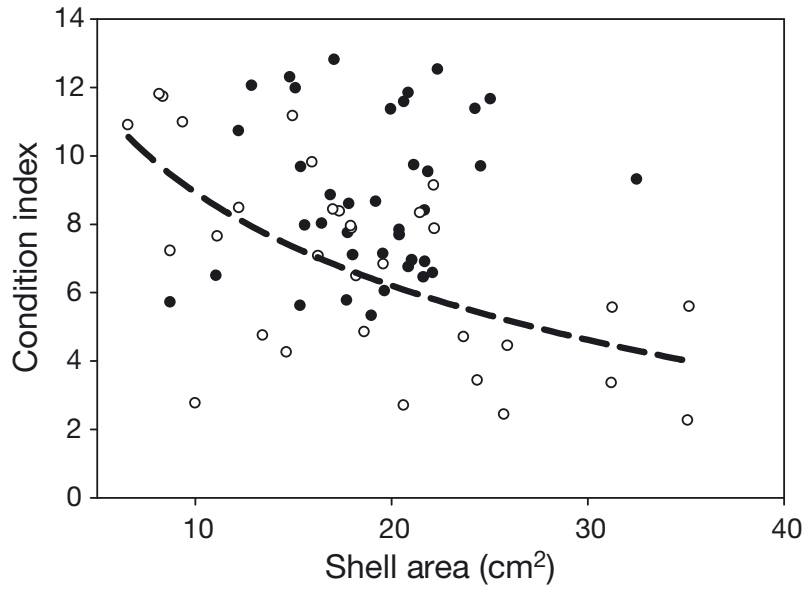

Fig. 6. Relationship between eastern oyster Crassostrea virginica size in left valve area (LVA) and condition index (CI). Filled circles: oysters without boring sponge Cliona celata infestation; open circles: sponge-colonized individuals. The significant regression is plotted with a dashed line for sponge-colonized oysters, where CI $=-3.922 \times \log ($ shell area) $+17.957 ; r^{2}=0.365, p<0.001$

icant negative relationship between colonized oyster size and tissue condition $(\mathrm{CI}=-3.922 \times \log$ [shell area $+17.957 ; \mathrm{r}^{2}=0.365, \mathrm{p}<0.001$; Fig. 6). In addition, there was a significant negative relationship between sponge biomass and oyster condition $(\mathrm{CI}=$ $8.253-[7.593 \times$ sponge biomass $] ; \mathrm{r}^{2}=0.220, \mathrm{p}=$ 0.004, Fig. 7A). Sponge biomass also significantly increased with shell area (sponge biomass $=0.0135 \times$ LVA - 0.0492; $r^{2}=0.350, p<0.001$, Fig. 7b).

\section{Clearance rate}

Oyster CRs were calculated to be $1.30 \pm 0.21 \mathrm{l} \mathrm{h}^{-1}$ for uncolonized oysters and $1.41 \pm 0.221 \mathrm{~h}^{-1}$ for colonized oysters, which were not significantly different $(t=-0.463, \mathrm{p}=0.646)$. For dry tissue weight specific relationships using a power function, the parameter estimates for $a$ were $1338 \pm 206 \mathrm{ml} \mathrm{h}^{-1}$ and $1325 \pm$ $254 \mathrm{ml} \mathrm{h}^{-1}$ for uncolonized and colonized oysters, respectively, while the exponent $b$ was $1.086 \pm 0.419$ and $0.898 \pm 0.409$ for uncolonized and colonized oysters, respectively. The exponents for the 2 models were not significantly different from each other $(t=$ $0.320, \mathrm{p}=0.751$ ).

Field prevalence

A total of 243 live oysters were collected from 30 quadrats, for a mean density of $7.8 \pm 0.7$ ind. 

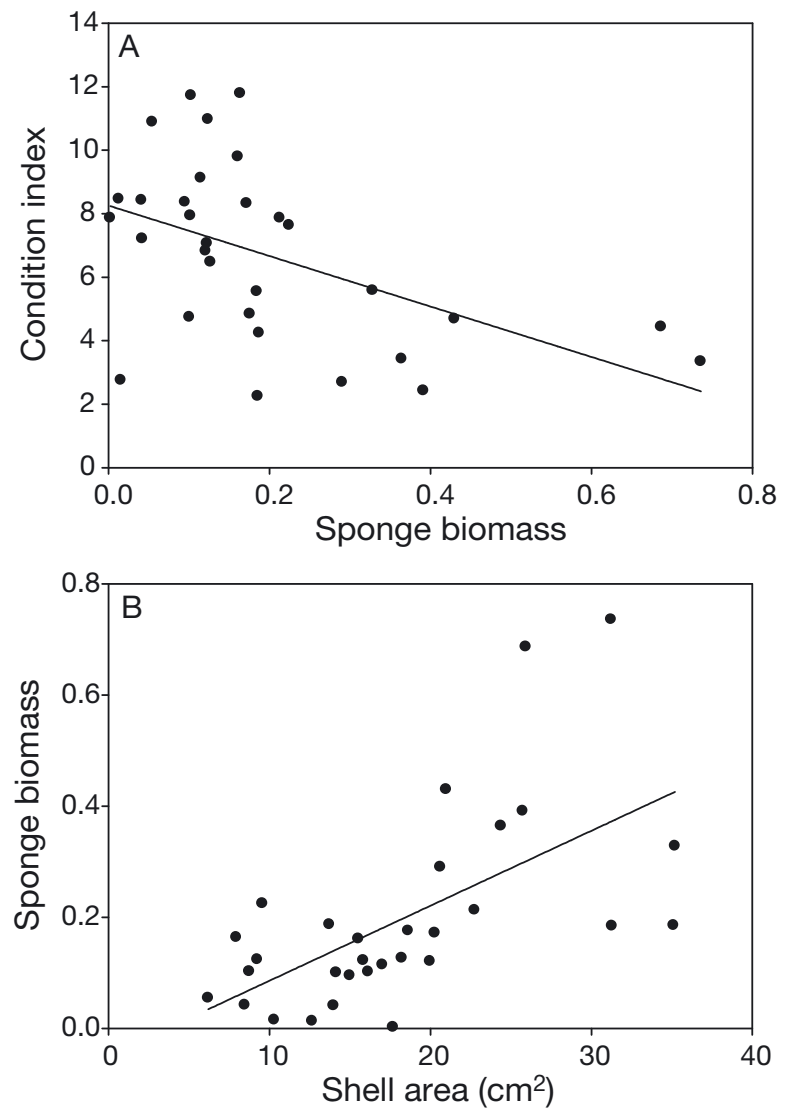

Fig. 7. Linear relationships from data pooled from both experiments between (A) eastern oyster Crassostrea virginica condition index (CI) and boring sponge Cliona celata biomass $(\mathrm{g})$, where $\mathrm{CI}=8.253-(7.593946 \times$ sponge biomass); $\mathrm{r}^{2}=0.220, \mathrm{p}=0.004$; and (B) sponge biomass and oyster shell area $\left(\mathrm{mm}^{2}\right.$, measured as the footprint area of the left valve, LVA), where sponge biomass $=0.0135 \times$ LVA $0.0492 ; r^{2}=0.350, p<0.001$

quadrat $^{-1}\left(195 \pm 16\right.$ oysters $\left.\mathrm{m}^{-2}\right)$. Of the oysters collected, sponges were present on $1.4 \pm 0.4$ oysters quadrat $^{-1}$ for a mean prevalence of $21.2 \pm 5.4 \%$ infestation on local intertidal oyster reefs. Sizes ranged from 32 to $122 \mathrm{~mm}$ for uncolonized $(73.8 \pm 1.2 \mathrm{~mm})$ and 44 to $130 \mathrm{~mm}$ for colonized oysters (84.5 \pm $3.2 \mathrm{~mm}$ ). Tissue condition of oysters from these intertidal reefs was $6.76 \pm 0.13$ for uncolonized oysters, significantly greater than the condition of colonized oysters $(5.50 \pm 0.32 ; t=4.035, \mathrm{p}<0.001)$. The parameter estimates for the length-weight allometric relationship for a were $86.07 \pm 1.08$ for uncolonized and $87.85 \pm 2.26$ for colonized oysters. The estimates for the exponent $b$ were $0.328 \pm 0.021$ for uncolonized and $0.383 \pm 0.058$ for colonized oysters, which were not different from each other $(t=-1.047, \mathrm{p}=0.296$, Fig. 8). There was a significant negative relationship between sponge biomass and oyster condition $(\mathrm{CI}=$

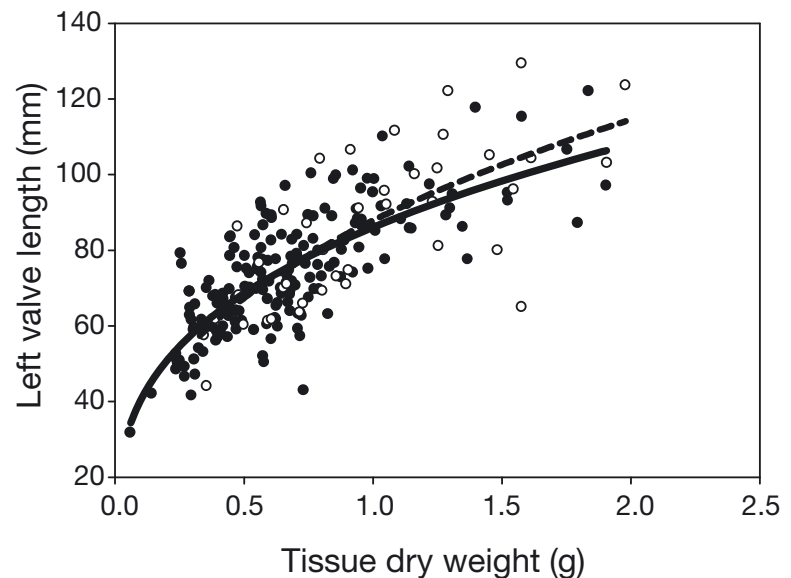

Fig. 8. Eastern oyster Crassostrea virginica left valve length (LVL, mm) versus tissue dry weight (TDW, g) for oysters with (open circles, dashed line) and without (filled circles, solid line) boring sponge Cliona celata infestation; oysters were collected from intertidal reefs in Hewlett's Creek, Wilmington, NC. Lines of fit represent the allometric relationship power function LVL $=a \mathrm{TDW}^{b}$. For uncolonized oysters, $\mathrm{LVL}=86.07 \mathrm{TDW}^{0.328}, \mathrm{p}<0.001$, and for sponge-colonized oysters, $\mathrm{LVL}=87.85 \mathrm{TDW}^{0.383}, \mathrm{p}<0.001$

$6.989-[2.011 \times$ sponge biomass $] ; \mathrm{r}^{2}=0.144, \mathrm{p}=$ 0.029; Fig. 9A). Sponge biomass also significantly increased with shell size (sponge biomass $=0.0122 \times$ shell height $-0.563 ; \mathrm{r}^{2}=0.306, \mathrm{p}<0.001$; Fig. 9B).

Similar to the growth experiment oysters, there was no difference in the number of new oyster spat per oyster whether the oysters were colonized $(1.00 \pm$ 0.21 spat oyster $\left.{ }^{-1}\right)$ or not $(0.81 \pm 0.07 ; t=-1.15, \mathrm{p}=$ 0.251). However, significantly more barnacles recruited to colonized oysters $(0.52 \pm 0.12$ barnacles oyster $\left.^{-1}\right)$ than uncolonized oysters $(0.25 \pm 0.06$; $t=$ $-2.046, \mathrm{p}=0.042$ ).

\section{DISCUSSION}

The impact of the boring sponge Cliona celata on eastern oysters Crassostrea virginica in this study was variable, dependent upon the experiment, oyster size, and the metric (growth, condition, etc.) used to determine the effect. In the first experiment, survival, growth, and condition were all significantly reduced in sponge-colonized oysters. Unfortunately, these results may have been confounded by colonized and uncolonized individuals being collected from different populations. Although recent water quality data suggests that environmental conditions are similar at the 2 sites, it is still possible that prior history and population differences affected the growth rate 

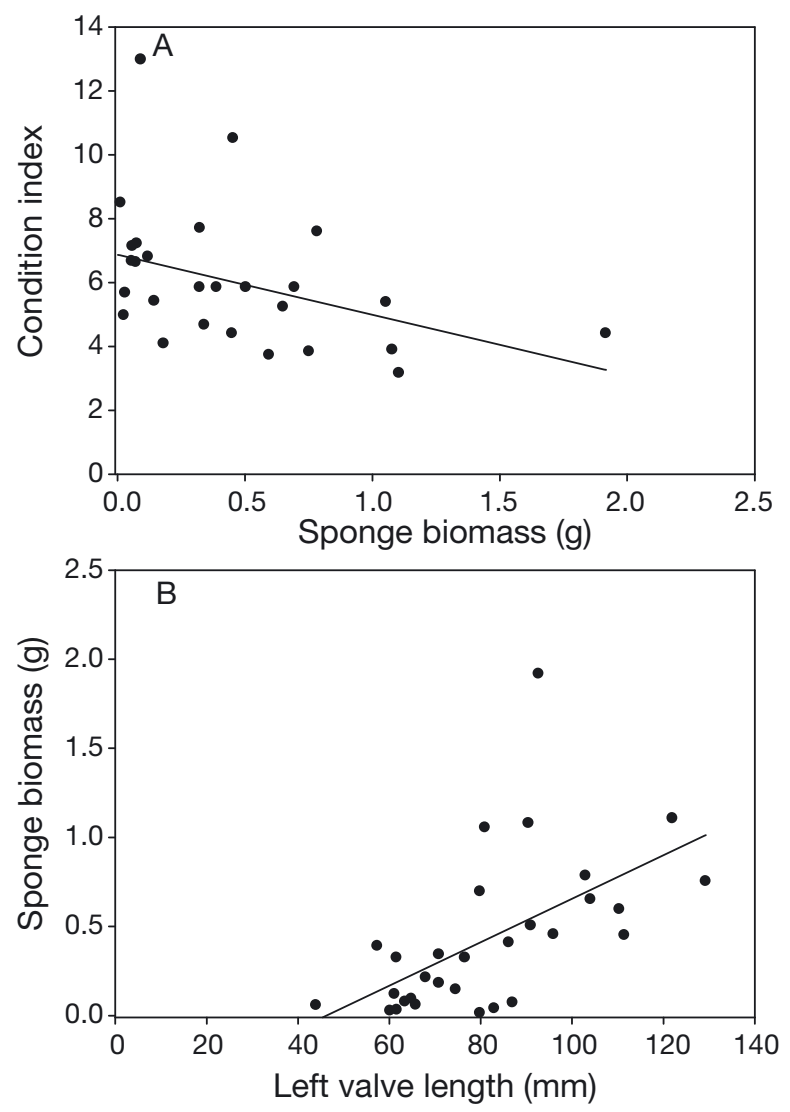

Fig. 9. (A) Eastern oyster Crassostrea virginica condition index (CI) versus boring sponge Cliona celata biomass (g), where $\mathrm{CI}=6.989-(2.011 \times$ sponge biomass $) ; \mathrm{r}^{2}=0.144, \mathrm{p}=0.029$. (B) Sponge biomass versus oyster left valve length (LVL, $\mathrm{mm}$ ), where sponge biomass $=0.0122 \times \mathrm{LVL}-0.563 ; \mathrm{r}^{2}=$ $0.306, \mathrm{p}<0.001$ for sponge-colonized oysters collected from intertidal oyster reefs in Hewlett's Creek, Wilmington, NC

and condition of the colonized individuals, making any differences between treatments not necessarily due to sponge presence. Therefore, we repeated the experiment with all oysters harvested from the same source, and again found significantly reduced growth rates and lower condition, albeit not significantly different. Lastly, our field surveys also demonstrated significantly reduced condition of colonized oysters, and showed similar negative relationships between sponge biomass and oyster condition as the experimental treatments. Thus, despite the potential confounding factors in the first experiment, the results were generally supported by the follow-up experiment and field survey.

Molluscan response to boring sponges in the literature has been equivocal. Numerous species, such as Ostrea edulis, Striostrea margaritacea, Clamys islandica, Haliotis iris, H. tuberculata, and Crepidula fornicata do not seem to be negatively affected by boring sponge presence (Schleyer 1991, Clavier 1992, Barthel et al. 1994, Rosell et al. 1999, Dunphy \& Wells 2001, Le Cam \& Viard 2011). However, in many of those cases, direct comparisons were not made between sponge-colonized and uncolonized individuals, but rather gradients of infection (Schleyer 1991, Rosell et al. 1999, Le Cam \& Viard 2011). For example, in a survey of $H$. iris across multiple sites in New Zealand, Dunphy \& Wells (2001) found that sponge infestation was prevalent at all locations but did not appear to have an adverse effect on abalone condition, while a later study by Nollens et al. (2003), which compared $H$. iris individuals with and without shell lesions, did show a significant effect on tissue and reproductive condition. Another direct comparison between colonized and uncolonized individuals of the periwinkle snail Littorina littorea also demonstrated a negative impact of boring sponge presence (Stefaniak et al. 2005).

Even among eastern oyster studies, results have been variable. When examining larval survival and settlement, studies have shown either negative impacts of sponge-colonized substrates (Barnes et al. 2010) or no effect of substrate infestation (Dunn et al. 2014b). For juvenile oysters, Dunn et al. (2014b) suggested that growth and survival were not affected by sponge presence - although direct comparisons were not made between colonized and uncolonized individuals, rather comparisons were made between individuals in bags with and without colonized substrates. Warburton (1958b) initially suggested the negative affect that sponges might have on oysters, however, only 'small numbers' of oysters were used, and no analysis performed, leading Warburton to suggest that 'more information is needed for firm conclusions.' Additionally, Warburton (1958b) also suggested that growth was similar, except for in a few heavily infested individuals that showed stunted growth, but as above, these results were qualitative. In fact, most studies of oysters in general have focused on what the sponge does to the shell, how that damage affects the culture industry, and what control strategies can be implemented (Warburton 1958a,c, Thomas 1979, Hoeksema 1983, Wesche et al. 1997, Carver et al. 2010, Daume et al. 2010).

In direct comparisons of sponge-colonized and uncolonized marsh periwinkles, those bored by sponges had significantly less shell and dry tissue mass, as well as thicker aperture lips than the non-bored individuals (Stefaniak et al. 2005). Abalone with shell lesions from unspecified boring organisms similarly experienced higher mortality, slower growth, and lower 
tissue and reproductive condition than those abalone that were not affected by lesions (Nollens et al. 2003). While similar quantitative studies for sponges on the eastern oyster are not available, oysters infested with another boring organism, the spionid polychaete Polydora sp., also exhibited significantly reduced growth and condition (Wargo \& Ford 1993, Handley 1998). Using direct comparisons, this study demonstrated that eastern oyster growth was consistently negatively affected by sponge presence across both experiments. CI was, as expected, significantly lower in sponge-colonized oysters during the first experiment, as well as in oysters harvested from intertidal reefs to examine sponge prevalence. However there was, unexpectedly, no difference in condition between oyster groups in the second experiment, which was confirmed by $\mathrm{C}: \mathrm{N}$ and energy content analysis. It is unclear why there was no significant difference in condition in the second experiment; colonized oysters from the field survey did exhibit significantly reduced condition, and they were harvested from the same site and source population as the oysters used in the second experiment.

It is possible that boring sponges might not have as dramatic an effect on smaller, younger oysters (Dunn et al. 2014b) as they do on larger, older individuals (Warburton 1958b), and the results from this study generally support this hypothesis. Smaller colonized oysters were used in the second experiment; colonized oysters had LVLs of $\sim 70 \mathrm{~mm}$ in Expt 1, whereas LVLs were $\sim 45 \mathrm{~mm}$ in Expt 2, and it is possible that these different starting sizes may have contributed to different effects observed between the experiments, specifically in regards to tissue condition. As mentioned previously, however, field surveyed oysters did exhibit significantly reduced condition, and these individuals were collected from the same site as those used in Expt 2. Regardless, for both experimental and field surveyed oysters, condition significantly declined with increasing sponge biomass, which increased with oyster size. When boring organisms infest oysters, the oysters transition energy away from growth and toward shell repair (Warburton 1958b, Handley 1998). It is possible that smaller oysters are able to maintain some balance between somatic growth and shell maintenance, but as the oyster grows larger repairing the shell becomes more costly (Palmer 1992), leading to an additional decline in somatic growth and subsequently condition. It is possible, then, that slower growth despite the same condition suggests oysters might invest a set amount of energy into building the shell, and in colonized oysters, more of that energy is diverted to repair rather than extension (Kennedy \& Breisch 1981). Additionally, larger oysters have to dedicate energy toward reproduction (Dame 1976), further reducing the amount of energy these individuals have to allocate to both shell repair and somatic growth.

While we expected that the mechanism driving treatment differences was shell repair, we did not measure this directly. Rather, we sought to eliminate other possibilities that might also cause differential growth, specifically, reduced feeding. Since the sponge can affect oyster valve operation by attacking the hinge and the attachment site of the adductor muscle, and also possibly alter internal shell space (Warburton 1958b, Thomas 1979, Hoeksema 1983), it could decrease both filtration rate and efficiency, which in turn could lead to reduced growth and condition. Lab filtration rates did not differ across sponge treatments, and neither tissue isotopic composition nor $\mathrm{C}: \mathrm{N}$ ratios from Expt 2 individuals varied with sponge presence. Together, these results suggest feeding efficiency/selectivity is unlikely to be impacted by sponge infestation, so the differences in growth between treatments are likely not resource-related. Since the impact of the boring sponge appears to be dependent to some degree on oyster size, and sponge presence does not impact the oysters' ability to obtain the resources necessary for growth, shell repair and maintenance is likely driving the observed effects of sponge presence on oysters, as expected.

Incidences of mortality caused by boring organisms are rare in the literature, and studies using $C$. celata have not typically demonstrated differential mortality among treatments. For eastern oysters, shell boring has been suggested as a potential cause of mortality in older oysters (Warburton 1958b, Carver et al. 2010). However, most studies over a range of organisms have concluded that the negative impacts on tissue condition caused by boring organisms, if observed, are not typically strong enough to cause mortality (Handley 1998, Rosell et al. 1999, Dunphy \& Wells 2001, Le Cam \& Viard 2011). In our first experiment, survival of caged, colonized oysters was significantly lower relative to uncolonized oysters, although this could have been attributable to the oyster source population and not necessarily the sponge itself. In the second experiment, there was no significant difference among treatments, although all oysters were smaller in the second experiment than the first. Since the sponge seems to have a stronger negative effect on larger individuals (as evidenced by the correlations between oyster condition, sponge biomass, and oyster size), it is possible that the higher relative mortality of oysters in the first experiment 
was because the sponge-colonized oysters were larger. Having reduced condition (as observed in the first experiment) can ultimately affect the individual's ability to withstand other environmental stressors (Rainer \& Mann 1992); thus, the cause of mortality in older, larger colonized individuals was likely indirect via other stressors (Guida 1977).

The boring sponge has also been implicated in indirect mortality of colonized individuals via predation. Through their boring activities, sponges weaken the shells and can decrease an individual's ability to survive attacks by predators (Wesche et al. 1997, Rosell et al. 1999, Dunphy \& Wells 2001, Le Cam \& Viard 2011). The presence of boring worms led to increased selection of both mussel (Ambariyanto \& Seed 1991) and gastropod prey (Buschbaum et al. 2007) by crab predators. Similarly, sponge-colonized periwinkles were easier to crush and chosen more frequently by crabs (Stefaniak et al. 2005); however, no corresponding study has been conducted for oysters. In this study, there was no sponge $\times$ cage interaction in the first experiment, and in the second experiment, there was $100 \%$ mortality of all oysters outside cages, regardless of sponge presence, within the first $2 \mathrm{wk}$. While the expectation was that colonized oysters would exhibit a greater decrease in survival relative to uncolonized oysters placed outside cages (which would indicate increased susceptibility), this was not observed. Furthermore, in flume experiments, neither blue crabs Callinectes sapidus nor xanthid crabs Panopeus herbstii preferentially selected colonized oysters (G. A. Diedrich \& J. M. Carroll unpubl. data); a similar lack of selectivity was observed with stone crabs Menippe mercenaria (Coleman 2014). However, since sponges reduce growth rate, this could potentially increase the window of vulnerability of juvenile oysters to size-specific potential predators (Carroll \& Finelli 2015). Regardless, these results suggest that the presence of boring sponges per se does not increase susceptibility to predation, but since previous studies have shown that predation differences occurred in laboratory settings, this issue warrants further investigation.

Results from our field surveys showed a negative effect of sponge presence on oyster condition and suggested a possible ontogenetic shift in the impact of the sponge. A total of $21 \%$ of the intertidal oysters at our survey site were infected with boring sponges. As anticipated, tissue condition of colonized individuals was significantly reduced relative to the condition of uncolonized individuals. However, no significant differences in the allometric relationship between length and dry tissue weight were ob- served. Since this relationship can be a proxy to compare growth among populations (Pollack et al. 2011), and growth rate experiments showed significantly reduced growth, we expected to observe different relationships. However, separation between the 2 growth curves started to occur as the collected individuals exceed $80 \mathrm{~mm} \mathrm{LVL}$, where colonized oysters of a similar size begin to have less dry tissue mass. Since it has been suggested that larger, older individuals are more likely to be affected by the sponge (Warburton 1958b, Carver et al. 2010, Dunn et al. 2014b), this separation makes sense. It is possible that had we sampled both a larger size range of individuals and had a larger sample size, these curves might have become significantly different.

Lastly, there has been some concern that sponge presence can affect oyster spat settlement (Barnes et al. 2010). However, a recent study indicated that oyster settlement was not negatively impacted by sponge presence in either lab or field experiments (Dunn et al. 2014b). Likewise, we did not observe differences in oyster recruitment to either colonized or uncolonized individuals on either our growth experiment oysters or oysters collected from the field. In addition to oysters, we also enumerated recruitment of other species to colonized or uncolonized oysters. With all species, there was no significant difference in recruitment, although barnacles and mussels were twice as abundant on colonized oysters. Thus, it does not seem that sponge presence should have a negative consequence on recruitment of oysters or development of reef communities, provided there is still available hard substrate (Dunn et al. 2014a,b).

In conclusion, while $C$. celata poses a serious cost to oyster culture (Warburton 1958b, Wells 1959, Fromont et al. 2005, Carver et al. 2010) and may be problematic for restored oyster reefs, particularly those which use limestone marl as a base (Lindquist et al. 2012, Dunn et al. 2014b), it is unclear what kind of impact the sponge might have on natural and restored oyster populations. The literature has produced variable results on the impacts of sponge presence across a suite of species, and our set of experiments also suggests that the impact is variable even within $C$. virginica. Growth and tissue condition of oysters in this study was significantly reduced in colonized relative to uncolonized oysters, although specific differences varied among the experiments and field surveys. Regardless, our results suggest that the impact of the boring sponge on oysters likely varies with oyster size (and presumably age), being more problematic for larger oysters. The effects of the sponge on oyster survival, either directly or indi- 
rectly, are still unclear, as both experiments varied in this regard as well. Clionid sponges have cosmopolitan distribution, and are likely to be unaffected by projected changes to ocean conditions (Duckworth \& Peterson 2013, Stubler et al. 2014), so it is possible that their negative impact might be exacerbated in the future. However, given the results reported in the literature as well as from our experiments, boring sponge impacts on wild oyster populations remain, unfortunately, unresolved. Further research should attempt to confirm the ontogenetic shift of sponge effects, and more comprehensive field surveys should be conducted in both intertidal and subtidal reefs to examine the full extent of this relationship.

Acknowledgements. We thank Jay Styron of Carolina Mariculture Company for providing us with colonized oysters for Expt 1, and Dr. Ami Wilbur, Director, UNCW Shellfish Hatchery for space and advice for both experiments. We also thank John Marion and Jessica Watts for help in sample processing, and Kim Duernberger from the Stable Isotope Geochemistry Lab at the UNCW Center for Marine Science for help with the isotope samples. Finally, we acknowledge funding from the University of North Carolina Wilmington.

\section{LITERATURE CITED}

Alagarswami K, Chellam A (1978) On fouling and boring organisms and mortality of pearl oysters in the farm at Veppalodai, Gulf of Mannar. Indian J Fish 23:10-22

- Ambariyanto, Seed R (1991) The infestation of Mytilus edulis Linnaeus by Polydora ciliata (Johnston) in the Conwy Estuary, North Wales. J Molluscan Stud 57:413-424

Anthony JA, Roby DE, Turco KR (2000) Lipid content and energy density of forage fishes from the northern Gulf of Alaska. J Exp Mar Biol Ecol 248:53-78

Barnes BB, Luckenbach MW, Kingsley-Smith PR (2010) Oyster reef community interactions: the effect of resident fauna on oyster (Crassostrea spp.) larval recruitment. J Exp Mar Biol Ecol 391:169-177

Barthel D, Sundet J, Barthel KG (1994) The boring sponge Cliona vastifica in a subarctic population of Chlamys islandica. An example of a balanced commensalism? In: van Soest R, van Kempen T, Braekman J (eds) Sponges in time and space. AA Balkema, Rotterdam, p 289-296

Benjamini Y, Hochberg Y (1995) Controlling the false discovery rate: a practical and powerful approach to multiple testing. J R Stat Soc B 57:289-300

Britton-Simmons KH (2004) Direct and indirect effects of the introduce alga Sargassum muticum on benthic subtidal communities of Washington state. Mar Ecol Prog Ser 277: 61-78

Buschbaum C, Buschbaum G, Schrey I, Thieltges DW (2007) Shell-boring polychaetes affect gastropod shell strength and crab predation. Mar Ecol Prog Ser 329:123-130

> Carroll JM, Finelli CM (2015) Impacts of the ectoparasitic snail Boonea impressa on growth of post-set juvenile oysters. J Molluscan Stud 81:161-163

- Carroll JM, Riddle K, Woods KE, Finelli CM (2015) Recruitment of the eastern oyster, Crassostrea virginica, in response to settlement cues and predation in North Carolina. J Exp Mar Biol Ecol 463:1-7

Carver CE, Thériault I, Mallet AL (2010) Infection of cultured eastern oysters Crassostrea virginica by the boring sponge Cliona celata, with emphasis on sponge life history and mitigation strategies. J Shellfish Res 29:905-915

Chambon C, Legeay A, Durrieu G, Gonzalez P, Ciret P, Massabuau JC (2007) Influence of the parasite worm Polydora sp. on the behaviour of the oyster Crassostrea gigas: a study of the respiratory impact and associated oxidative stress. Mar Biol 152:329-338

Clavier J (1992) Infestation of Haliotis tuberculata shells by Cliona celata and Polydora species. In: Shepherd S, Tegner MJ, Guzman del Proo S (eds) Abalone of the world: biology, fisheries and culture. Supplementary papers. Department of Fisheries of South Australia, Adelaide, p $16-20$

Coleman SE (2014) The effects of boring sponge on oyster soft tissue, shell integrity, and predator-related mortality. MSc thesis, University of North Carolina, Chapel Hill, NC

> Coughlan J (1969) The estimation of filtering rate from the clearance of suspensions. Mar Biol 2:356-358

Dame RF (1972) Comparison of various allometric relationships in intertidal and subtidal American oysters. Fish Bull 70:1121-1126

> Dame RF (1976) Energy flow in an intertidal oyster population. Estuar Coast Mar Sci 4:243-253

Dame RF (1996) Ecology of marine bivalves: an ecosystem approach. CRC Press, Boca Raton, FL

> Dattagupta S, Bergquist DC, Szalai EB, Macko SA, Fisher CR (2004) Tissue carbon, nitrogen, and sulfur stable isotope turnover in transplanted Bathymodiolus childressi mussels: relation to growth and physiological condition. Limnol Oceanogr 49:1144-1151

> Daume S, Fromont J, Parker F, Davidson M, Murphy D, Hart A (2010) Quantifying sponge erosions in Western Australian pearl oyster shells. Aquacult Res 41:e260-e267

Duckworth AR, Peterson BJ (2013) Effects of seawater temperature and $\mathrm{pH}$ on the boring rates of the sponge Cliona celata in scallop shells. Mar Biol 160:27-35

> Dunn RP, Eggleston DB, Lindquist N (2014a) Effects of substrate type on demographic rates of eastern oyster (Crassostrea virginica). J Shellfish Res 33:177-185

> Dunn RP, Eggleston DB, Lindquist N (2014b) Oyster-sponge interactions and bioerosion of reef-building substrate materials: implications for oyster restoration. J Shellfish Res 33:727-738

Dunphy BJ, Wells RMG (2001) Endobiont infestation, shell strength and condition index in wild populations of the New Zealand abalone, Haliotis iris. Mar Freshw Res 52: 781-786

- Fodrie FJ, Rodriguez AB, Baillie CJ, Brodeur MC and others (2014) Classic paradigms in a novel environment: inserting food web and productivity lessons from rocky shores and saltmarshes into biogenic reef restoration. J Appl Ecol 51:1314-1325

Fromont J, Craig R, Rawlinson L, Alder J (2005) Excavating sponges that are destructive to farmed pearl oysters in Western and Northern Australia. Aquacult Res 36: 150-162

Gnaiger E, Bitterlich G (1984) Proximate biochemical composition and caloric content calculated from elemental CHN analysis: a stoichiometric concept. Oecologia 62: 289-298 
Guida VG (1977) The physiological ecology of the oysterburrowing sponge symbiosis and the roles of symbioses in marine systems. $\mathrm{PhD}$ dissertation, North Carolina State University, Raleigh, NC

Handley SJ (1998) Power to the oyster: Do spionid-induced shell blisters affect condition in subtidal oysters? J Shellfish Res 17:1093-1099

> Handley SJ, Bergquist PR (1997) Spionid polychaete infestations of intertidal pacific oysters, Crassostrea gigas (Thunberg), Mahurangi Harbour, northern New Zealand. Aquaculture 153:191-205

Hartman WD (1958) Natural history of marine sponges of southern New England. Bull Peabody Mus Nat Hist 12: $1-155$

Hoeksema BW (1983) Excavation patterns and spiculae dimensions of the boring sponge Cliona celata from the SW Netherlands. Seckenb Marit 15:55-85

$>$ Hopkins SH (1962) Distribution of species of Cliona (boring sponge) on the eastern shore of Virginia in relation to salinity. Chesap Sci 3:121-124

Kaufmann KW (1981) Fitting and using growth curves. Oecologia 49:293-299

Kelly CJ, Laramore SE, Scarpa J, Newell RIE (2011) Seasonal comparison of physiological adaptation and growth of Suminoe (Crassostrea ariakensis) and eastern (Crassostrea virginica) oysters. J Shellfish Res 30:737-749

Kennedy VS, Breisch LL (1981) Maryland's oysters: research and management, Vol 81. University of Maryland, College Park, MD

Le Cam S, Viard F (2011) Infestation of the invasive mollusc Crepidula fornicata by the native shell borer Cliona celata: a case of high parasite load without detrimental effects. Biol Invasions 13:1087-1098

Le Vay L, Gamboa-Delgado J (2011) Naturally-occurring stable isotopes as direct measures of larval feeding efficiency, nutrient incorporation and turnover. Aquaculture 315:95-108

Lindquist N, Fodrie J, Tyler A, Cessna D, Karam A, Kuan C (2012) Cliona spp. boring sponge in North Carolina oyster reefs: distribution, abundance and impacts. Presentation at the 41st Benthic Ecology Meeting, 21-24 March 2012, Norfolk, VA

Lunz GR Jr (1943) The yield of certain oyster lands in South Carolina. Am Midl Nat 30:806-808

- Malet N, Sauriau PG, Faury N, Soletchnik P, Guillou G (2007) Effect of seasonal variation in trophic conditions and the gametogenic cycle on $\delta^{13} \mathrm{C}$ and $\delta^{15} \mathrm{~N}$ levels of diploid and triploid Pacific oysters Crassostrea gigas. Mar Ecol Prog Ser 346:203-217

> McKinstry CAE, Westgate AJ, Koopman HN (2013) Annual variation in the nutritional value of Stage V Calanus finmarchicus: implications for right whales and other copepod predators. Endang Species Res 20:195-204

Nelson KA, Leonard LA, Posey MH, Alphin TD, Mallin MA (2004) Using transplanted oyster (Crassostrea virginica) beds to improve water quality in small tidal creeks: a pilot study. J Exp Mar Biol Ecol 298:347-368

> Newell RIE, Kennedy VS, Shaw KS (2007) Comparative vulnerability to predators, and induced defense responses, of eastern oysters Crassostrea virginica and non-native Crassostrea ariakensis oysters in Chesapeake Bay. Mar Biol 152:449-460

Nollens HH, Keogh JA, Probert K (2003) Effects of shell

Editorial responsibility: Stephen Feist,

Weymouth, UK lesions on survival, growth, condition and reproduction in the New Zealand blackfoot abalone Haliotis iris. Dis Aquat Org 57:127-133

> Palmer AR (1992) Calcification in marine mollusks: How costly is it? Proc Natl Acad Sci USA 89:1379-1382

Pollack JB, Kim HC, Morgan EK, Montagna PA (2011) Role of flood disturbance in natural oyster (Crassostrea virginica) population maintenance in an estuary in South Texas, USA. Estuaries Coasts 34:187-197

> Pomponi SA (1980) Cytological mechanisms of calcium carbonate excavation by boring sponges. Int Rev Cytol 65: 301-319

Rainer JS, Mann R (1992) A comparison of methods for calculating condition index in eastern oysters, Crassostrea virginica (Gmelin, 1791). J Shellfish Res 11:55-58

Rheault RB, Rice MA (1996) Food-limited growth and condition index in the eastern oyster, Crassostrea virginica (Gmelin 1791), and the bay scallop, Argopecten irradians irradians (Lamarck 1819). J Shellfish Res 15:271-283

$>$ Rosell D, Uriz MJ, Martin D (1999) Infestation by excavating sponges on the oyster (Ostrea edulis) populations of the Blanes littoral zone (north-western Mediterranean Sea). J Mar Biol Assoc UK 79:409-413

Rützler K (2002) Impact of crustose clionid sponges on Caribbean reef corals. Acta Geol Hisp 37:61-72

> Rützler K, Rieger G (1973) Sponge burrowing: fine structure of Cliona tampa penetrating calcareous substrata. Mar Biol 21:144-162

Schleyer MH (1991) Shell-borers in the oyster, Striostrea margaritacea: Pests or symbionts? Symbiosis 10:135-144

Stefaniak LM, McAtee J, Shulman MJ (2005) The costs of being bored: effects of a clionid sponge on the gastropod Littorina littorea (L). J Exp Mar Biol Ecol 327:103-114

Stubler AD, Furman BT, Peterson BJ (2014) Effects of $\mathrm{pCO}_{2}$ on the interaction between an excavating sponge, Cliona varians, and a hermatypic coral, Porites furcata. Mar Biol 161:1851-1859

Sumerel AN, Finelli CM (2014) Particle size, flow speed, and body size interactions determine feeding rates of a solitary ascidian, Styela plicata: a flume experiment. Mar Ecol Prog Ser 495:193-204

Thomas PA (1979) Boring sponges destructive to economically important molluscan beds and coral reefs in Indian seas. Indian J Fish 26:163-200

Warburton FE (1958a) Control of the boring sponge on oyster beds. Fish Res Board Can Prog Rep Atl Coast Stn 69: $7-11$

Warburton FE (1958b) The effects of boring sponges on oysters. Fish Res Board Can Prog Rep Atl Coast Stn 68:3-8

- Warburton FE (1958c) The manner in which the sponge Cliona bores in calcareous objects. Can J Zool 36: 555-562

> Wargo RN, Ford SE (1993) The effect of shell infestation by Polydora sp. and infection by Haplosporidium nelsoni (MSX) on the tissue condition of oysters, Crassostrea virginica. Estuaries 16:229-234

Wells HW (1959) Boring sponges (Clionidae) of Newport River, North Carolina. J Elisha Mitchell Sci Soc 75: 168-173

- Wesche SJ, Adlard RD, Hooper JNA (1997) The first incidence of clionid sponges (Porifera) from the Sydney rock oyster Saccostrea commercialis (Iredale and Roughley, 1933). Aquaculture 157:173-180

Submitted: April 27, 2015; Accepted: September 10, 2015

Proofs received from author(s): October 27, 2015 